\title{
NETWORK LOAD BALANCING DENGAN MENGGUNAKAN WINDOWS SERVER 2003
}

\author{
Sri Rahayu ${ }^{1}$ \\ Syarah ${ }^{2}$ \\ Hadi Wijaya $^{3}$
}

E-mail : sri@ raharja.info, syarah@raharja.info, hadiwijaya@sk.raharja.ac.id

\begin{abstract}
ABSTRAK
Penanganan dan perawatan sebuah jaringan komputer di lingkungan suatu organisasi/instansi sering menghadapi masalah. Masalah-masalah tersebut biasanya terletak pada masalah keamanan, masalah kehandalan, ketersediaan dan skalabilitas jaringan komputer. Untuk memecahkan masalah tersebut maka untuk itu akan dibuat sistem layanan Load Balancing dan juga Cluster Service yang dapat meningkatkan kehandalan dan kecepatan untuk membuka sistem aplikasi berbasis web dan sistem jaringan computer.
\end{abstract}

Kata Kunci : Load Balancing, Cluster Service, Web

\begin{abstract}
Handling and maintenance of a computer network within an organization / agency often face problems. These problems are usually located on security issues, reliability issues, availability and scalability of computer networks. To solve the problem then it will be made for service systems Load Balancing and Cluster Service that can increase the reliability and speed to open up a web-based application system and computer network systems.
\end{abstract}

Keywords: Load Balancing, Cluster Service, Web

\footnotetext{
${ }^{1}$ Dosen Sistem Informasi STMIK Raharja Informatika

Jl. Jend.Sudirman No. 40 Modern Cikokol-Tangerang 15117

${ }^{1}$ Dosen Sistem Komputer STMIK Raharja Informatika

Jl. Jend.Sudirman No. 40 Modern Cikokol-Tangerang 15117

${ }^{1}$ Mahasiswa AMIK Bina Sarana Informatika

Cabang Bumi Serpong Damai
} 


\section{PENDAHULUAN}

Penanganan dan perawatan sebuah jaringan komputer di lingkungan suatu organisasi/instansi sering menghadapi masalah. Masalah-masalah tersebut biasanya terletak pada masalah keamanan, masalah kehandalan, ketersediaan dan skalabilitas jaringan komputer. Untuk merealisasikan penggunaan jaringan komputer yang dapat mengimplementasikan seluruh aplikasi berbasis web perlu adanya penyesuaian infrastruktur sesuai kebutuhan. Implementasi seluruh aplikasi berbasis web diperkirakan membutuhkan sebuah konfigurasi server yang handal dan juga dapat mengantisipasi kebutuhan masa depan. Implementasi sistem jaringan komputer yang akan dilaksanakan di lingkungan suatu organisasi akan menjadi suatu prototipe sistem jaringan komputer untuk organisasi lainnya. Dengan jumlah pengguna jaringan komputer berjumlah lebih dari 1000 orang yang akan menggunakan fasiltas aplikasi layanan berbasis web maka dibutuhkan sebuah konfigurasi server yang handal. Selain sisi konfigurasi hardware yang menjadi pertimbangan agar server nanti handal maka terdapat layanan-layanan yang ada pada server harus bisa mengantisipasi pengaksesan aplikasi berbasis web tersebut secara simultan dan mempunyai frekuensi yang sangat tinggi. Untuk itu akan diimplementasikan layanan Load Balancing dan juga Cluster Service yang dapat meningkatkan kehandalan dan kecepatan untuk membuka sistem aplikasi berbasis web dan sistem jaringan komputer. Sebelum hal tersebut dilakukan maka infrastruktur jaringan komputer untuk lingkungan suatu organisasi/instansi harus disesuaikan dengan kebutuhan.

\section{PERMASALAHAN}

Berdasarkan latar belakang dan pengamatan yang dilakukan, maka dapat diuraikan beberapa permasalahan yang dihadapai, yaitu bagaimana mengatasi dan membagi beban pengaksesan aplikasi berbasis web dan aplikasi server yang akan terus meningkat cukup tinggi ke dalam beberapa komputer server agar beban tersebut tidak hanya terletak pada satu server saja.

\section{HASIL DAN PEMBAHASAN}

\section{Setup cluster host}

Kami akan berjalan selama beberapa langkah untuk mengaktifkan NLB pada host masing-masing. Anda pertama dapat melakukan ini untuk server pertama dan setelah itu untuk yang kedua. Kami telah mengambil screenshot dari konfigurasi kedua server. Screenshot dari server pertama terletak di sebelah kiri, yang lain, server dua screenshot spesifik, terletak di sebelah kanan.

Langkah pertama adalah untuk memverifikasi alamat ip Anda mengatur untuk server. Pergi ke properti dari antarmuka jaringan anda:

\section{Gambar 1. Setting ip address}

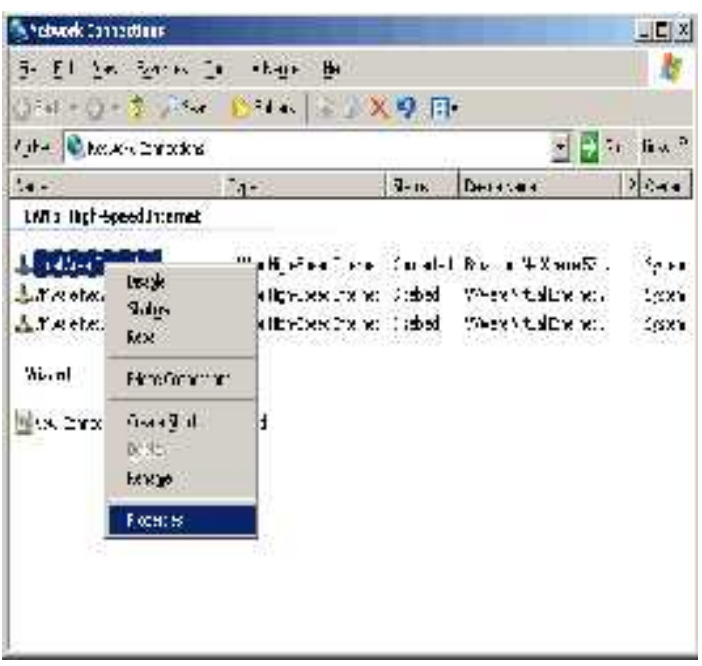

Gambar 1. Setting ip address 
Pergi ke properti dari Internet Protocol (TCP/IP)

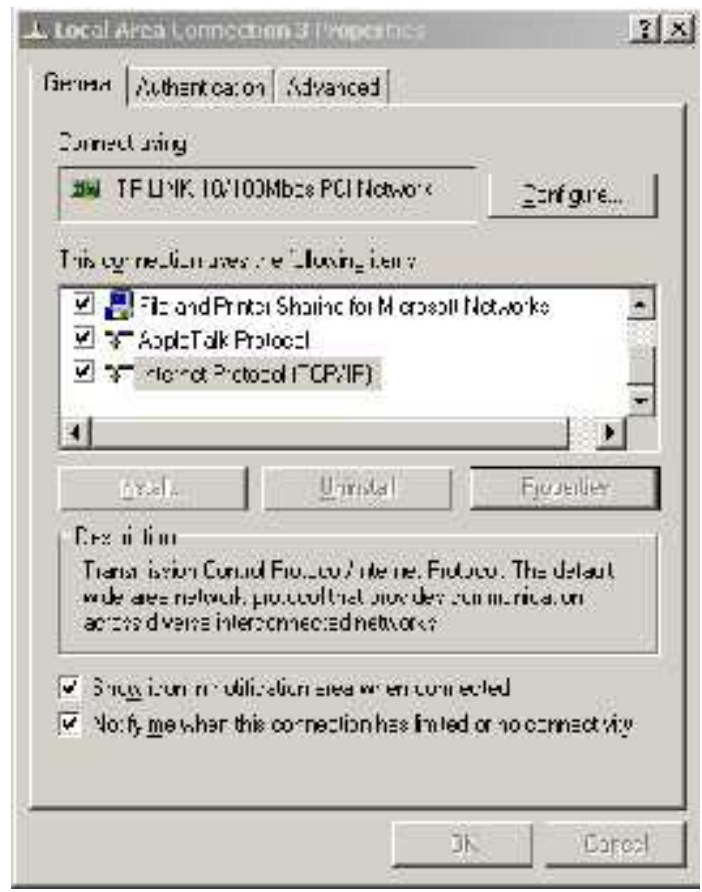

Gambar 2. Setting ip address

Periksa alamat ip statis untuk server. Alamat ip akan digunakan kemudian sebagai berdedikasi alamat ip. Dalam situasi normal, hal ini ip address wont tersedia dari luar.

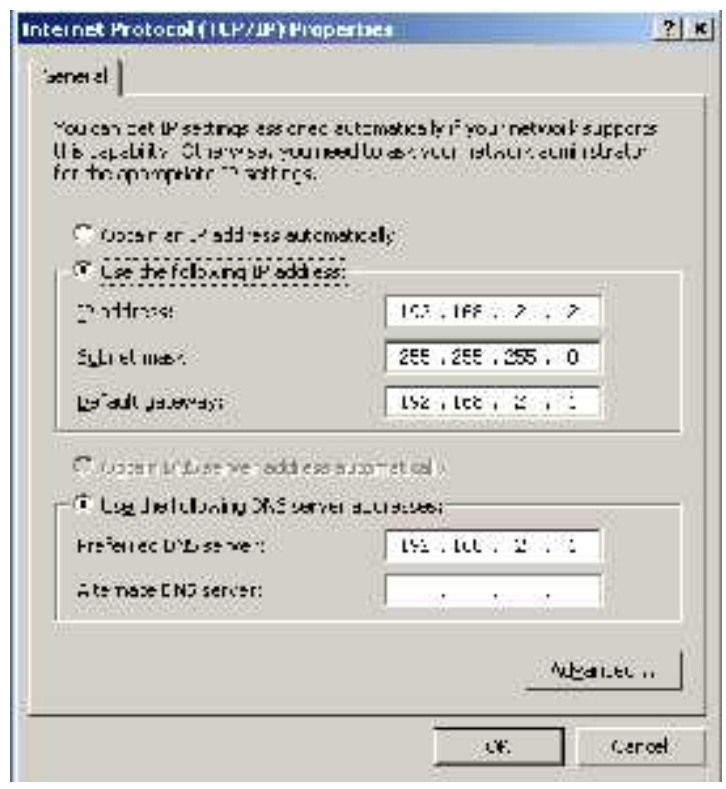

Gambar 3. Jendela setting ip
Aktifkan Jaringan Load Balancing dan pergi ke sifat:

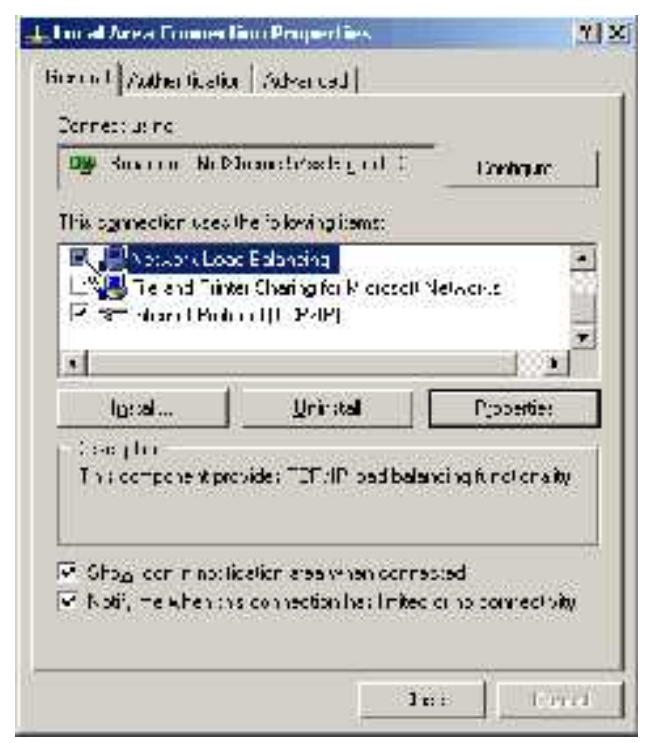

Gambar 4. Aktif Load Balancing

Sekarang kita akan mengkonfigurasi Parameter Cluster. Konfigurasi ini adalah sama untuk kedua server. ip Alamat yang Anda mengkonfigurasi sini harus ditambahkan ke daftar alamat ip dari Internet Protocol (TCP / IP). Anda harus memilih modus cluster operasi Anda, kemungkinan adalah unicast atau multicast. Kedua kemungkinan ini memiliki kelebihan dan kekurangan.

a. Mode unicast Perubahan mode unicast adaptor cluster alamat MAC ke alamat MAC cluster. Alamat cluster adalah alamat MAC yang sama yang digunakan pada semua host cluster. Ketika perubahan ini dibuat, klien tidak bisa lagi alamat adapter cluster dengan alamat MAC asli mereka.

b. Modus Multicast Bila menggunakan mode multicast, NLB akan menambah akses MAC multicast ke adapter cluster pada semua host cluster. Pada saat yang sama, adapter cluster mempertahankan alamat MAC yang asli mereka. Dengan cara ini setiap host dapat diatasi secara individual 
Load Balancing Jaringan driver tidak mendukung unicast dicampur lingkungan multicast. Semua penghuni cluster harus baik multicast atau unicast, jika tidak, cluster ini tidak akan berfungsi dengan baik.

Jika klien mengakses Load Balancing Jaringan cluster melalui router ketika cluster telah dikonfigurasi untuk beroperasi dalam mode multicast, pastikan bahwa router memenuhi persyaratan sebagai berikut:

a. Menerima sebuah Address Resolution

Protocol (ARP) menjawab bahwa memiliki satu alamat MAC dalam payload struktur ARP tetapi nampaknya datang dari sebuah stasiun dengan alamat MAC, sebagaimana dinilai oleh header Ethernet.

b. Menerima balasan ARP yang memiliki alamat MAC multicast dalam payload struktur ARP.

Jika router Anda tidak memenuhi persyaratan ini, Anda dapat membuat entri ARP statis di router. Sebagai contoh, beberapa router memerlukan entri ARP statis karena mereka tidak mendukung resolusi alamat IP unicast multicast alamat MAC.

Anda juga dapat mengaktifkan Internet Group Management Protocol (IGMP) dukungan di cluster host untuk mengendalikan banjir beralih ketika beroperasi dalam mode multicast. IGMP adalah sebuah protokol yang digunakan oleh Internet Protocol versi 4 (IPv4) host untuk melaporkan keanggotaan grup multicast mereka ke router multicast segera tetangga.

Ketika Anda mengaktifkan remote control Anda dapat mengelola semua konfigurasi NLB pada satu host dengan manajer NLB (ini akan dibahas kemudian). Bila Anda mengaktifkan remote control, Anda harus memberikan password yang identik pada kedua host cluster.

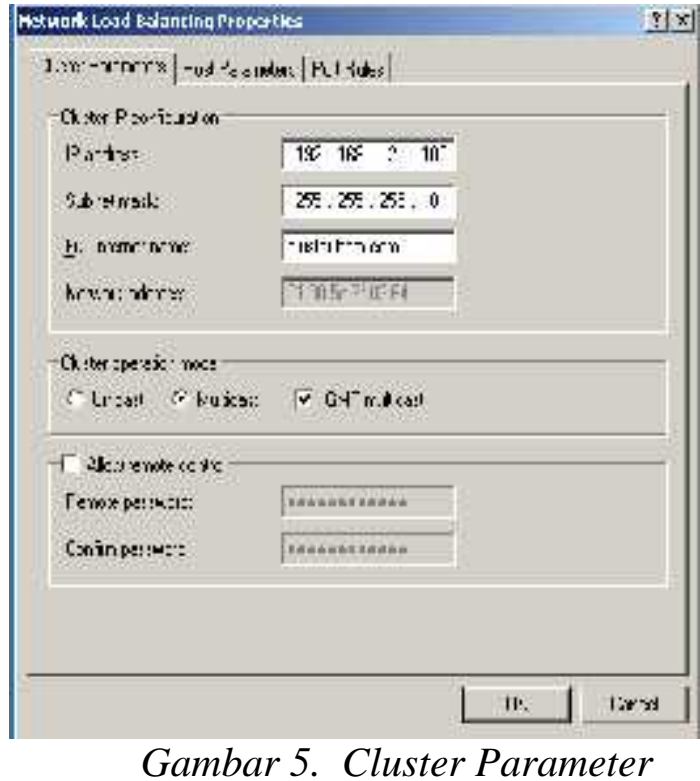

Tab sebelumnya identik untuk kedua host cluster, parameter tab Host adalah unik untuk setiap host cluster. Setiap host harus memiliki alamat ip khusus, sebagaimana disebutkan sebelumnya. Dengan host pengenal unik Anda bisa menentukan klaster host tuan rumah akan menjadi default, saat tidak ada aturan berlaku untuk permintaan tersebut. Anda juga perlu menentukan yang merupakan negara tuan rumah awal.

Sekarang Anda dapat setup aturan pelabuhan untuk permintaan. Anda harus ingat bahwa Anda harus setup jumlah yang sama aturan port pada setiap host cluster. Aturan-aturan ini juga harus cocok dalam jangkauan port, protokol dan modus penyaringan. Dalam konfigurasi yang kita mengusulkan, tidak perlu aturan port setup. Prioritas didefinisikan dalam tab "Parameter Host". 


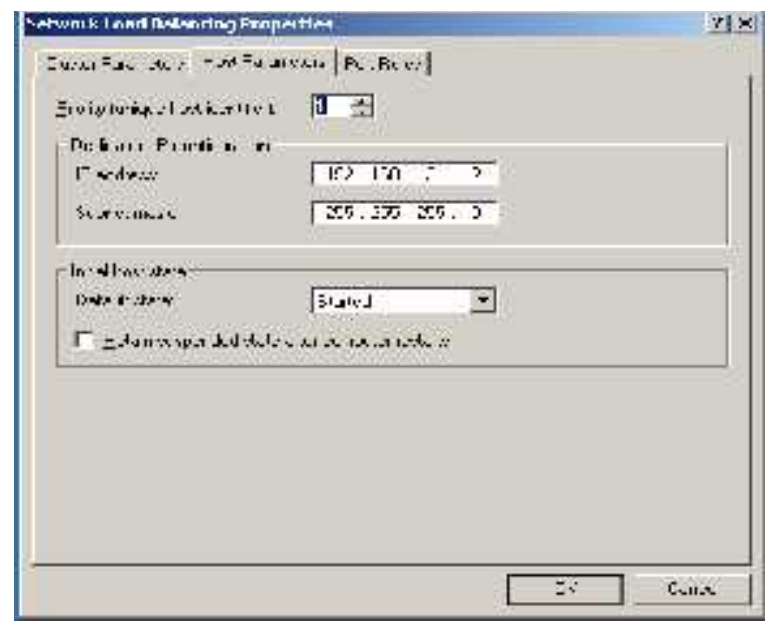

Gambar 6. Prioritas Host Parameter

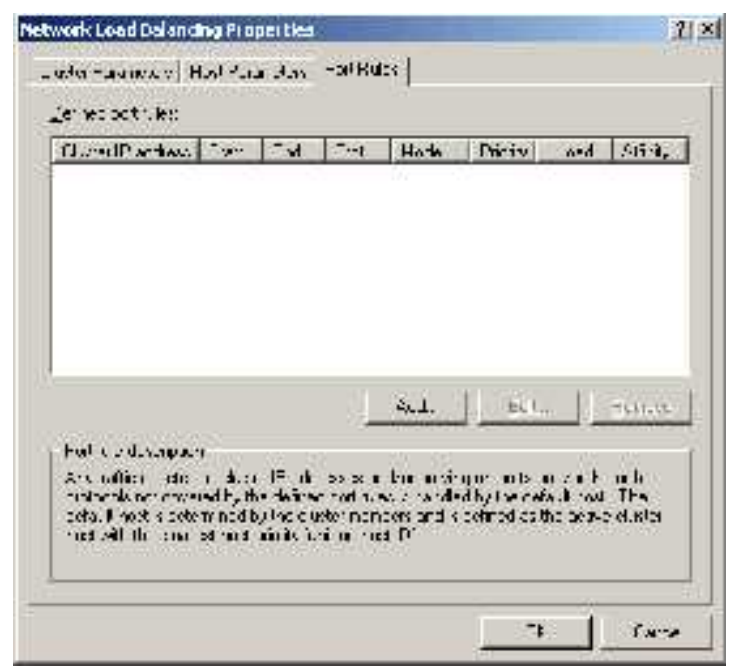

Gambar 7. Port Rules

Bila Anda menekan "Ok", Anda akan menerima pemberitahuan berikut:

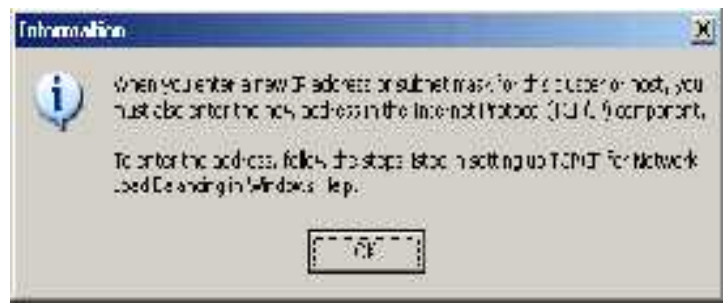

Gambar 8. Persetujuan setting ip
Anda perlu menambahkan alamat ip cluster ke Internet Protocol (TCP / IP) stack.

Pergi ke sifat Internet Protocol (TCP / IP), tekan berikutnya tombol Advanced.

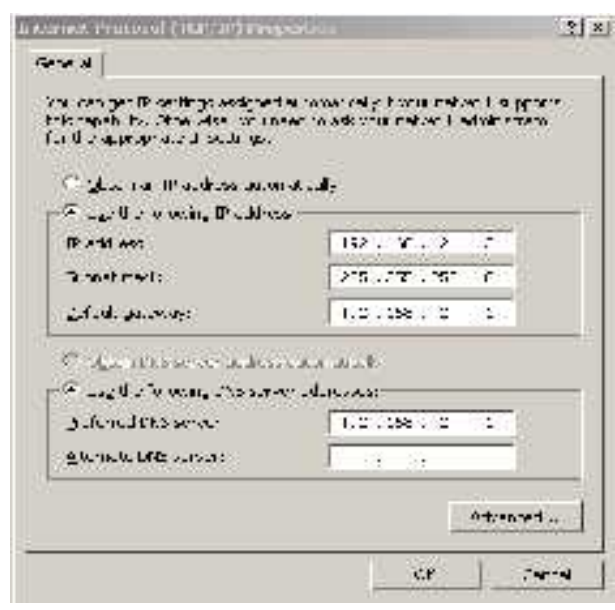

Gambar 9. Tcp/ip

Tambahkan cluster ip 192.168.2.100 ke daftar alamat Ip. Anda harus melakukan ini untuk kedua host cluster.

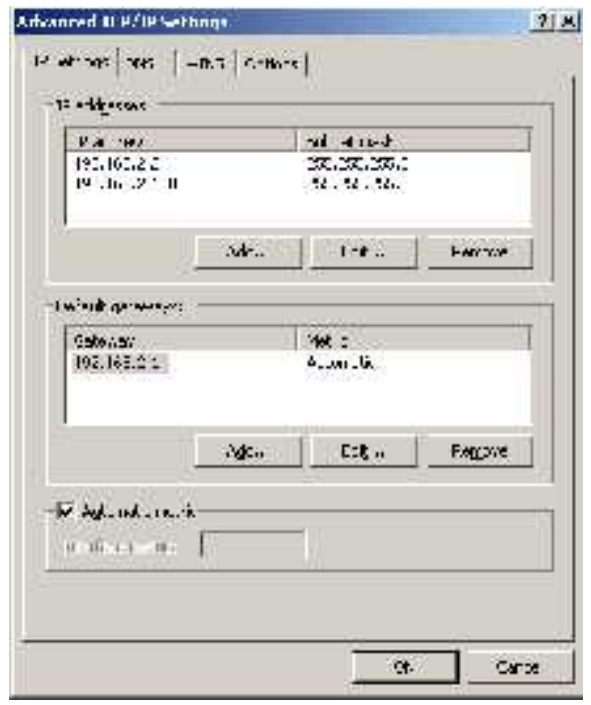




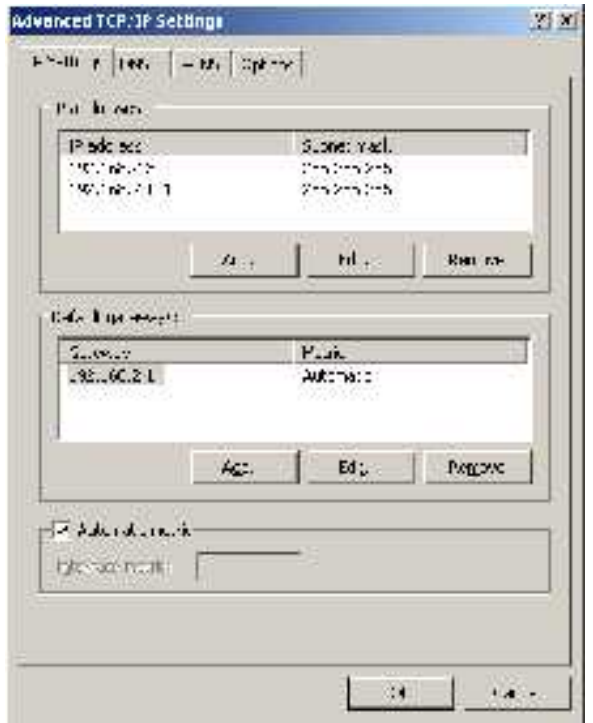

Gambar 10. Ip setting

Pelaksanaan NLB sekarang selesai.

\section{Test dan Hasil Performa Network Load} Balancing

a. Performa Server Tanpa Menggunakan Network Load Balancing

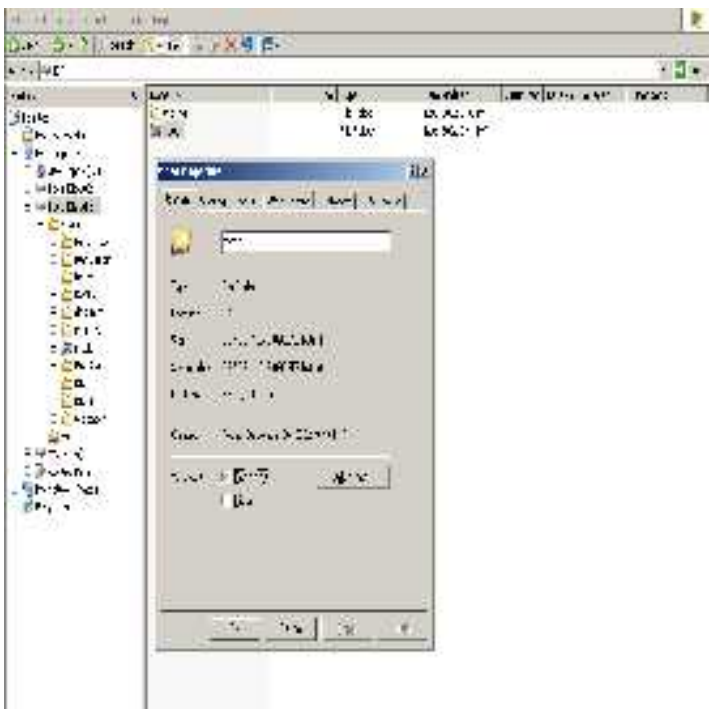

Gambar 11. Size File yang di Sharing
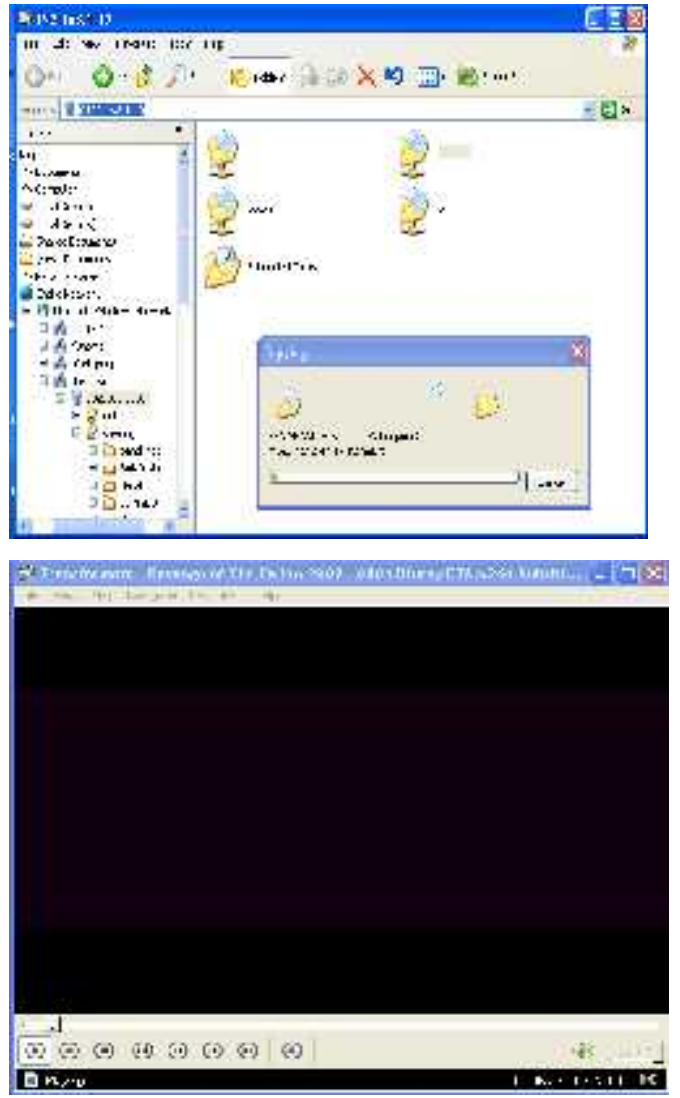

Gambar 12. Proses Pengcopyan dan Pemutaran video

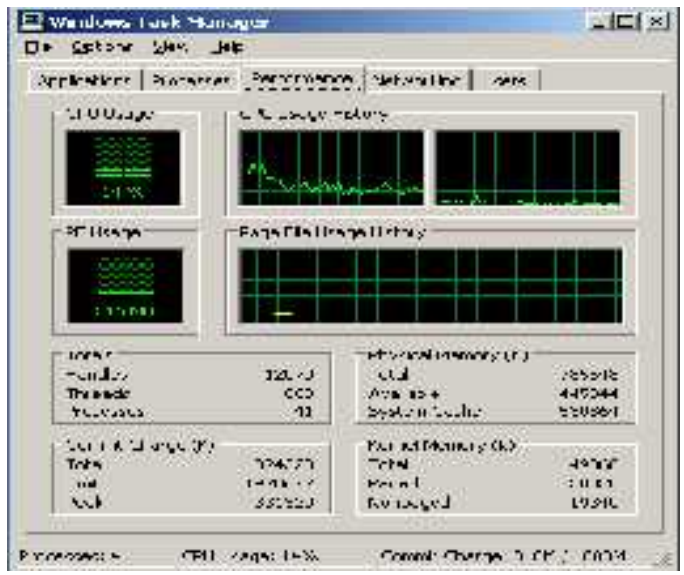

Gambar 13. Performa CPU tanpa NLB

Dari hasil test diatas membuktikan bahwa kinerja server tanpa menggunakan NLB dapat diketahui bahwa performa cpu sebesar $14 \%$. 
a. Performa Server Tanpa Menggunakan Network Load Balancing.
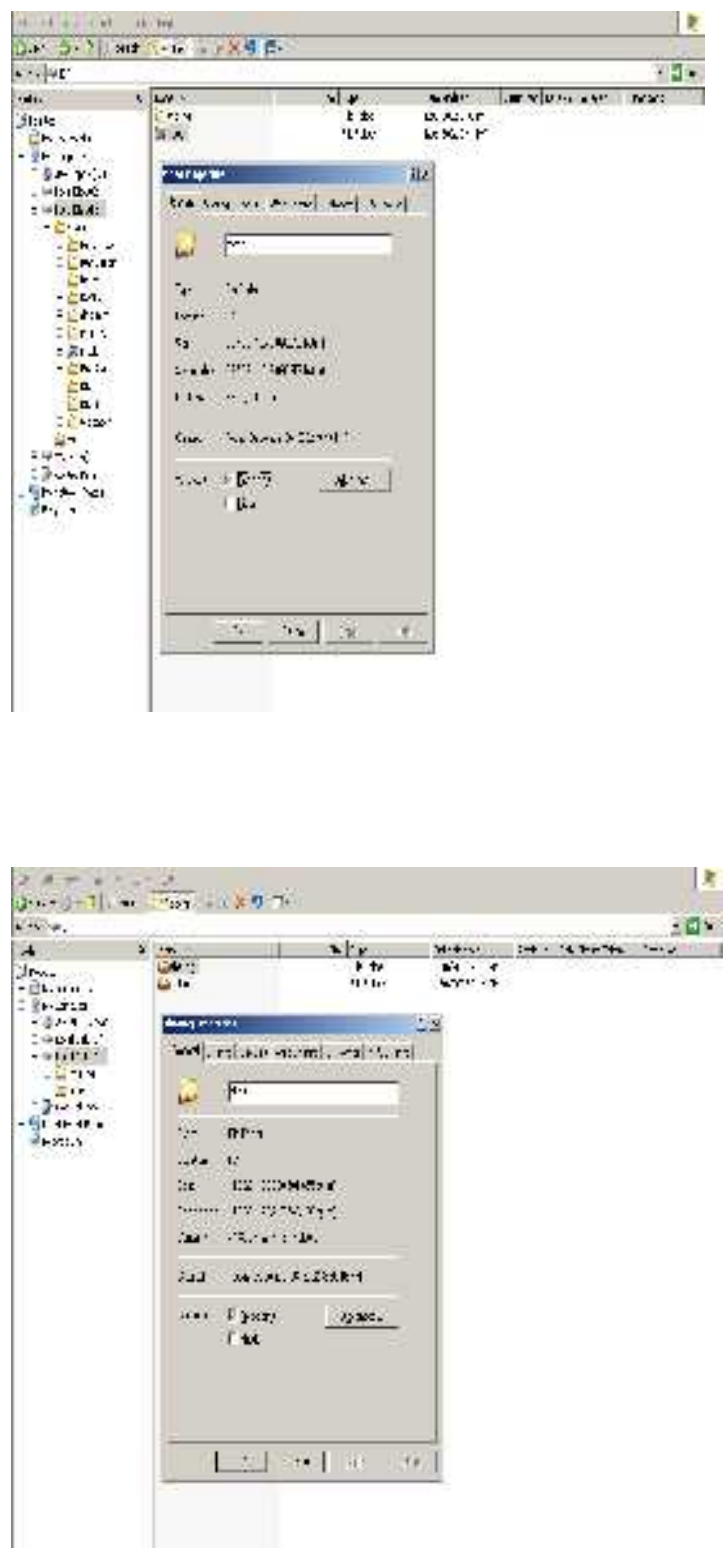

Gambar 14. Size File yang di Sharing
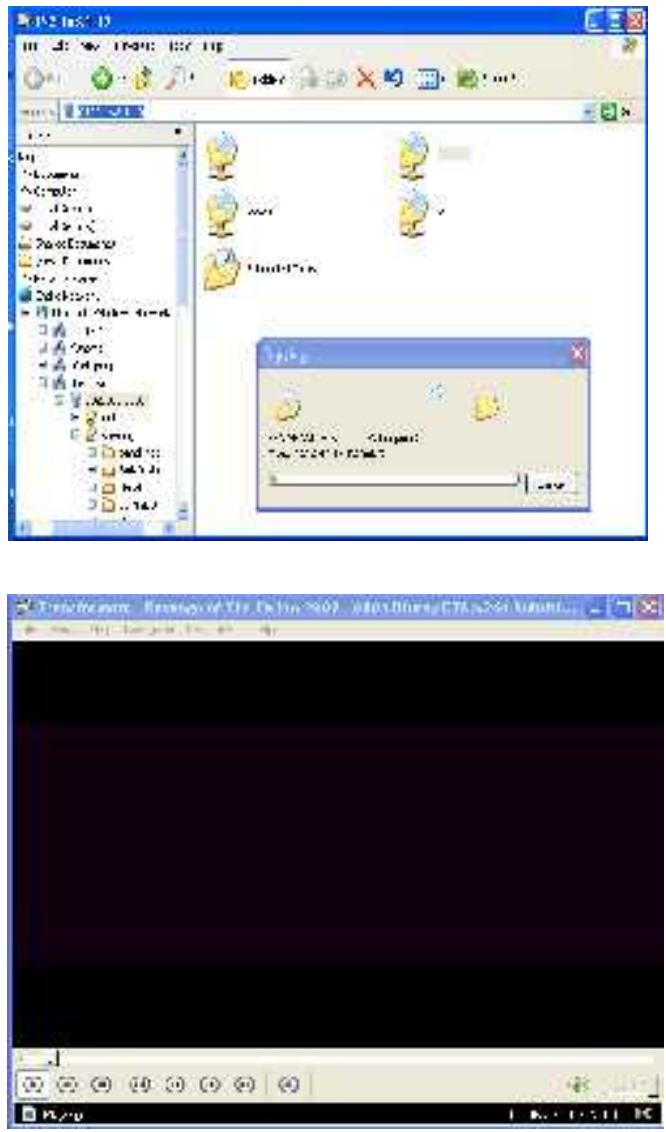

Gambar 15. Proses Pengcopyan dan Pemutaran video

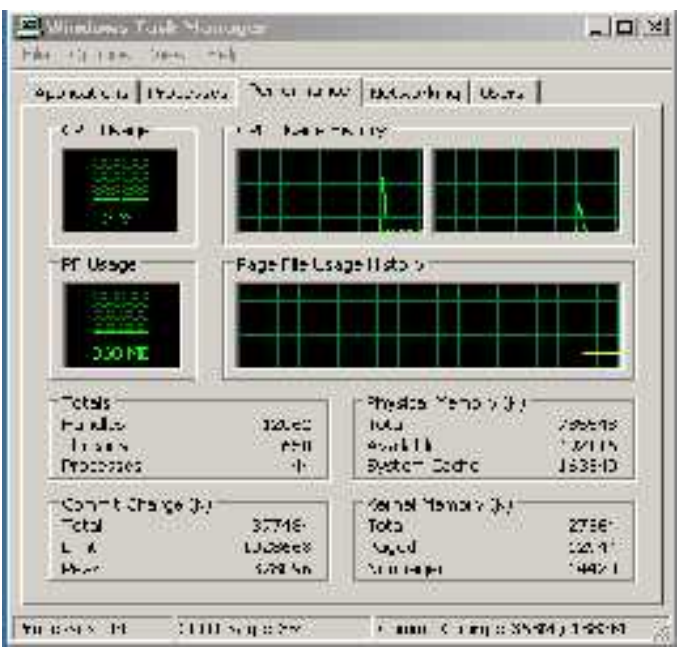

Gambar 16. Proses Performa CPU dengan $N L B$

Dari hasil test diatas membuktikan bahwa kinerja server dengan menggunakan NLB 
dapat diketahui bahwa performa cpu sebesar $3 \%$.

\section{Mengelola Jaringan Load Balancing}

Bila Anda diaktifkan remote control pada Parameter Cluster, Anda dapat menggunakan Load Balancing Network Manager. Manajer NLB bisa dimulai dari baris perintah: Nlbmgr.exe atau dengan pergi ke alat-alat Administrasi pada menu Start.

Network Load Balancing Manager digunakan untuk membuat dan mengelola Load Balancing Jaringan cluster dan semua host cluster dari satu komputer, dan Anda juga bisa meniru konfigurasi cluster ke host lain. Dengan memusatkan tugas-tugas administrasi, Network Load Balancing Manager membantu menghilangkan banyak kesalahan konfigurasi yang umum.

Microsoft, Windows, Windows Server 2003 adalah salah satu merek dagang atau merek dagang dari Microsoft Corporation di Amerika Serikat dan / atau negara lain.

Itulah serangkaian konfigurasi yang dilakukan pada windows server 2003 untuk membuat NLB Mudah-mudahan bisa berguna dalam menambah wawasan ilmu pengetahuan bagi mahasiswa pada khususnya dan bagi masyarakat pada umumnya.

\section{Kesimpulan}

Berdasarkan pada uraian-uraian yang peneliti lakukan pada bab sebelumnya maka peneliti dapat menyimpulkan beberapa hal sebagai berikut:

a. Teknik ini (load balancing) berfungsi untuk mendistribusikan beban trafik pada dua atau lebih jalur koneksi secara seimbang.

b. memperkecil waktu tanggap dan menghindari overload pada salah satu jalur koneksi c. Loadbalance tidak akan menambah besar bandwidth yang kita peroleh, tetapi hanya bertugas untuk membagi trafik dari kedua bandwidth tersebut agar dapat terpakai secara seimbang

\section{DAFTAR PUSTAKA}

1. http://bayuart.wordpress.com/2007/0 8/02/2-isp-1-lan/

2. http://dennycharter.wordpress.com

3. http://en.wikipedia.org/wiki/Load_ba lancing_(computing)

4. http://www.pc24.co.id/article/categor y40_1.htm

5. http://support.microsoft.com/?LN=e n-us\&pr=lifecycle 